\title{
Actinomadura keratinilytica sp. nov., a keratin- degrading actinobacterium isolated from bovine manure compost
}

\author{
Aaron A. Puhl, ${ }^{1}$ L. Brent Selinger, ${ }^{2}$ Tim A. McAllister $^{1}$ \\ and G. Douglas Inglis ${ }^{1}$ \\ ${ }^{1}$ Agriculture and Agri-Food Canada Research Centre, 5403 1st Avenue S, Lethbridge, AB T1J \\ 4B1, Canada \\ ${ }^{2}$ Department of Biological Sciences, University of Lethbridge, 4401 University Drive, Lethbridge, AB \\ T1K 3M4, Canada
}

Correspondence

G. Douglas Inglis

inglisd@agr.gc.ca

\begin{abstract}
A novel keratinolytic actinobacterium, strain WCC- $2265^{\top}$, was isolated from bovine hoof keratin 'baited' into composting bovine manure from southern Alberta, Canada, and subjected to phenotypic and genotypic characterization. Strain WCC- $2265^{\top}$ produced well-developed, nonfragmenting and extensively branched hyphae within substrates and aerial hyphae, from which spherical spores possessing spiny cell sheaths were produced in primarily flexuous or straight chains. The cell wall contained meso-diaminopimelic acid, whole-cell sugars were galactose, glucose, madurose and ribose, and the major menaquinones were $\mathrm{MK}-9\left(\mathrm{H}_{6}\right), \mathrm{MK}-9\left(\mathrm{H}_{8}\right), \mathrm{MK}-$ $9\left(\mathrm{H}_{4}\right)$ and $\mathrm{MK}-9\left(\mathrm{H}_{2}\right)$. These characteristics suggested that the organism belonged to the genus Actinomadura and a comparative analysis of $16 \mathrm{~S}$ rRNA gene sequences indicated that it formed a distinct clade within the genus. Strain WCC $-2265^{\top}$ could be differentiated from other species of the genus Actinomadura by DNA-DNA hybridization, morphological and physiological characteristics and the predominance of iso- $C_{16: 0}$, iso- $C_{17: 0}$ and 10 -methyl $C_{17: 0}$ fatty acids. The broad range of phenotypic and genetic characters supported the suggestion that this organism represents a novel species of the genus Actinomadura, for which the name Actinomadura keratinilytica sp. nov. is proposed; the type strain is strain WCC- $2265^{\top}$ (=DSM $45195^{\top}=$ CCUG $56181^{\top}$ ).
\end{abstract}

The ability to degrade keratin, the insoluble structural protein of feathers, wool and horn (Bradbury, 1973), is not widely distributed among bacteria. Among the actinobacteria, this activity has been well characterized in many species within the genus Streptomyces (Noval \& Nickerson, 1959; Young \& Smith, 1975; Mukhopadhyay \& Chandra, 1990) and keratinolytic activity has been reported from species belonging to the genera Saccharomonospora, Amycolatopsis and Terrabacter (Al-Zarban et al., 2002; AlMusallam et al., 2003; Montero-Barrientos et al., 2005).

The description of the family Thermomonosporaceae was recently amended and the family currently contains four genera: Actinomadura, Actinocorallia, Spirillospora and

Abbreviation: SEM, scanning electron microscopy.

The GenBank/EMBL/DDBJ accession numbers for the 16S rRNA gene sequences of strain WCC- $2265^{\top}$ and Actinomadura rubrobrunea DSM $43750^{\top}$ are EU637009 and EU637008, respectively.

A table showing the fatty acid profiles of strain $\mathrm{WCC}-2265^{\top}$ and related strains and a figure showing the growth of strain $\mathrm{WCC}^{-2265^{\top}}$ on keratin agar are available with the online version of this paper.
Thermomonospora (Zhang et al., 2001). The revised description of the genus Actinomadura by Zhang et al. (2001) accommodates aerobic, Gram-positive, non-acidfast, non-motile actinobacteria that typically produce well-developed, extensively branched, non-fragmenting vegetative hyphae and aerial hyphae that differentiate into chains of spores of various shapes and ornamentation. All members of the genus Actinomadura possess type III cell walls (containing meso-diaminopimelic acid) and the acyl group of the muramic acid is of the acetyl type. Madurose can be found in the whole-cell sugars of most species. The predominant menaquinone types are $\mathrm{MK}-9\left(\mathrm{H}_{4}\right)$, MK$9\left(\mathrm{H}_{6}\right)$ and $\mathrm{MK}-9\left(\mathrm{H}_{8}\right)$. The total cellular fatty acid pattern is type $3 \mathrm{a}$ (saturated, unsaturated and branched fatty acids plus tuberculostearic acid) (Kroppenstedt \& Goodfellow, 1991), except for Actinomadura rubrobrunea and Actinomadura viridilutea, which can be distinguished from other species of the genus Actinomadura by the relatively high proportions of iso-branched and low proportions of 10-methyl-branched fatty acids they produce. These differences have been attributed to the thermophilic nature of A. rubrobrunea and A. viridilutea 

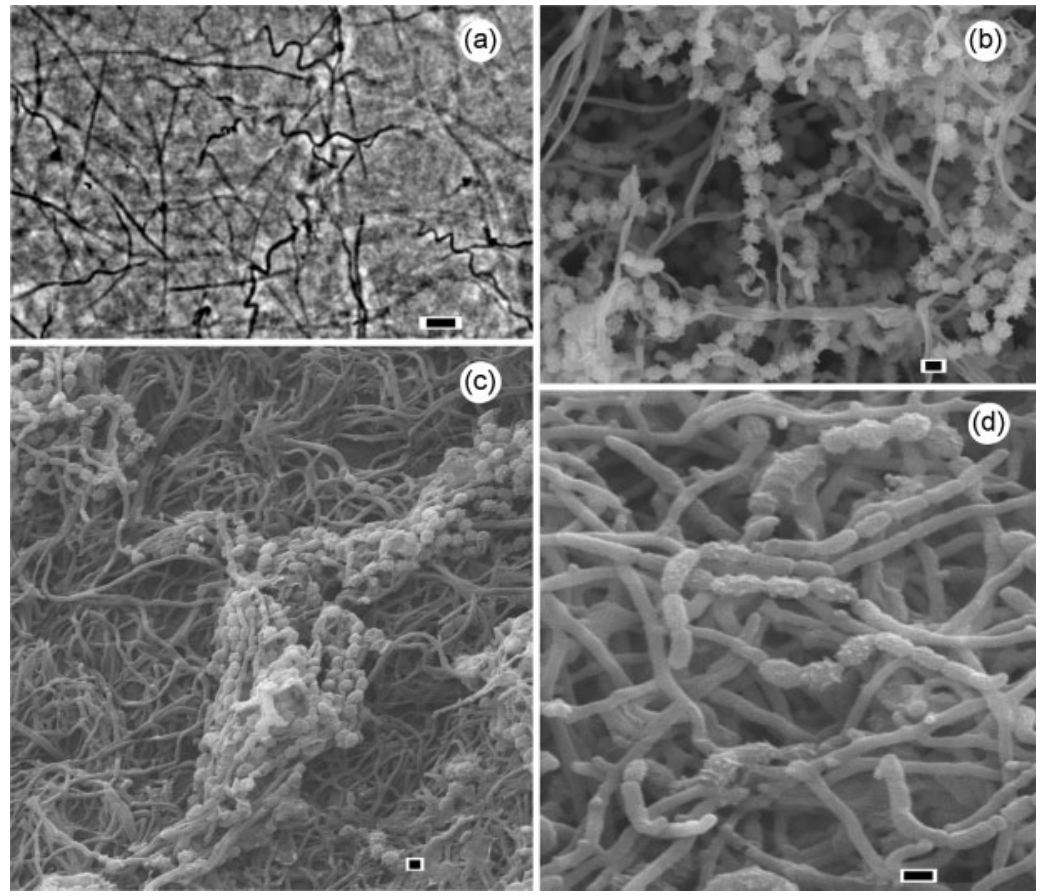

Fig. 1. Morphology of strain WCC $-2265^{\top}$ viewed by: (a) light microscopy showing substrate hyphae grown in ISP 2 medium for 14 days; (b) SEM of a vapour-fixed sample showing clusters of mature conidia on keratin agar (KA); (c) SEM of a glutaraldehyde-fixed sample showing aerial hyphae and conidia on $\mathrm{KA}$; (d) SEM of a glutaraldehyde-fixed sample showing differentiation of aerial hyphae into conidia on KA. Bars, $1 \mu \mathrm{m}$.

relative to other Actinomadura species (Kroppenstedt et al., 1990).

Here, the polyphasic characterization and classification of strain WCC-2265 ${ }^{\mathrm{T}}$, isolated in 2007 from composting bovine manure in Lethbridge, Alberta, Canada, are described. Strain WCC- $2265^{\mathrm{T}}$ had genotypic and phenotypic properties that are typical of species of the genus Actinomadura and displayed the ability to degrade keratin and utilize it as a sole carbon and nitrogen source.

Strain WCC- $2265^{\mathrm{T}}$ was isolated from coarsely ground bovine hoof $(25 \mathrm{~g})$ that had been enclosed in $5 \times 10 \mathrm{~cm}$ polyester bags (pore size, $50 \mu \mathrm{m}$; ANKOM Technology) and buried within a model compost system that consisted of a matrix primarily composed of bovine manure (Xu et al., 2009). Baited hoof samples were removed periodically over a 10 month period and $1 \mathrm{~g}$ material was homogenized in $10 \mathrm{ml}$ PBS (100 mM, pH 7.2) amended with $0.01 \%$ (v/v) Tween 80 with a Stomacher 80 Biomaster (Brinkmann). This suspension was serially diluted with $100 \mathrm{mM}$ PBS, spread in duplicate onto keratin agar (KA), and incubated at $45{ }^{\circ} \mathrm{C}$ for 2, 4, 7 and 14 days. KA was a basal medium containing $5 \mathrm{mM} \mathrm{KH}_{2} \mathrm{PO}_{4}$ (pH 7.5), $8.5 \mathrm{mM} \mathrm{NaCl}, 2 \mathrm{mM} \mathrm{MgSO}_{4}$ and $1 / 1000(\mathrm{v} / \mathrm{v})$ trace-salt solution $\left(1 \mathrm{~g} \mathrm{l}^{-1}\right.$ each of $\mathrm{FeSO}_{4} \cdot 7 \mathrm{H}_{2} \mathrm{O}$, $\mathrm{MnCl}_{2} \cdot 4 \mathrm{H}_{2} \mathrm{O}$ and $\left.\mathrm{ZnSO}_{4} \cdot 7 \mathrm{H}_{2} \mathrm{O}\right)$, amended with $10 \mathrm{~g} \mathrm{l}^{-1}$ bovine hoof or poultry feathers that had been milled to a fine powder with an MM-200 ball grinder (Retsch). Following isolation, strain WCC- $2265^{\mathrm{T}}$ was maintained on tryptic soy agar and KA; it was also kept as a hyphal fragment and spore suspension in $20 \%(\mathrm{v} / \mathrm{v})$ glycerol at $-80{ }^{\circ} \mathrm{C}$.

For comparative purposes, A. rubrobrunea DSM $43750^{\mathrm{T}}$ and A. viridilutea DSM $44433^{\mathrm{T}}$ were included in the study because phylogenetic analysis with all recognized species of the genus Actinomadura indicated that they were the most closely related to strain WCC- $2265^{\mathrm{T}}$. The strains that were tested were grown on KA, yeast/malt extract agar [International Streptomyces Project medium 2 (ISP 2)], oatmeal agar (ISP 3), and inorganic salts-starch agar (ISP 4) (Shirling \& Gottlieb, 1966) at $45{ }^{\circ} \mathrm{C}$ following inoculation with a fresh spore suspension. Growth and morphology were examined at 2, 7 and 14 days. The colour of the substrate hyphae was determined from the reverse side as described by Shirling \& Gottlieb (1966). Cell morphology was observed and measurements were made under a light microscope with an ocular micrometer and by scanning electron microscopy (SEM). For SEM, the agar blocks containing the organism (cultivated on KA and ISP 2 for 7 and 14 days at $45{ }^{\circ} \mathrm{C}$ ) were fixed with either $2 \%$ glutaraldehyde and critical-point-dried or with the vapour of $1 \%$ osmium tetroxide and air-dried. Samples were sputter-coated with gold and viewed with a Hitachi S-570 microscope operated at $20 \mathrm{kV}$.

The morphological characteristics of strain WCC- $2265^{\mathrm{T}}$ were consistent with those of members of the genus Actinomadura. Strain WCC- $2265^{\mathrm{T}}$ grew well on all of the media tested and colonies could be observed after $24 \mathrm{~h}$. The bacterium produced well-developed, non-fragmenting and extensively branched substrate hyphae that often formed long open coils (Fig. 1a). Colonies were opaque, raised and rubbery in consistency, with a wrinkled surface on ISP 2. On ISP 3 and ISP 4, colonies were raised and smooth. The substrate hyphae of the colonies were yelloworange on ISP 2 and grey-white on ISP 3 and ISP 4. On KA, strain WCC- $2265^{\mathrm{T}}$ produced white floccose aerial 
hyphae after $48 \mathrm{~h}$ incubation at $45{ }^{\circ} \mathrm{C}$. Aerial hyphae were wider in diameter, on average, than substrate hyphae ( $1 \mu \mathrm{m}$ compared with approximately $0.3 \mu \mathrm{m}$, respectively), were extensively branched and differentiated into straight or flexuous chains of up to 15 spiny spores with a mean diameter of $1.2 \mu \mathrm{m}$ (Fig. 1). Mature spores were spherical and, en masse, were blue-green in colour and powdery in appearance. Aerial hyphae did not undergo autolysis upon sporulation, which is a characteristic feature of both $A$. rubrobrunea and A. viridilutea (Agre \& Guzeva, 1975). Strain WCC- $2265^{\mathrm{T}}$ could break down insoluble hoof and feather keratin within KA, producing an obvious zone of clearing (see Supplementary Fig. S1, available in IJSEM Online).

Growth was tested over a range of temperatures (25$\left.65{ }^{\circ} \mathrm{C}\right), \mathrm{NaCl}$ concentrations $(0-9 \% \mathrm{w} / \mathrm{v})$ and $\mathrm{pH}$ values ( $\mathrm{pH} 4.0-10.0$ ) on ISP 2 and ISP 3. For $\mathrm{pH}$ adjustments, media were amended with $75 \mathrm{mM}$ sodium citrate $(\mathrm{pH} 4.0$ 7.0) or BIS/TRIS/propane ( $\mathrm{pH} 7.0-10.0)$ at the respective $\mathrm{pH}$. Carbohydrate utilization was tested using ISP 9 medium as described by Shirling \& Gottlieb (1966). Constitutive enzymic activities were tested using an API ZYM test kit according to the manufacturer's instructions (bioMérieux; Humble et al., 1977). Cells were grown for $48 \mathrm{~h}$ in GPYB broth (Greiner-Mai et al., 1987), pelleted, resuspended in distilled water containing $0.85 \% \mathrm{NaCl}(6$ McFarland standard) and incubated in the test strip cupules for $4 \mathrm{~h}$ at $45{ }^{\circ} \mathrm{C}$. Colour intensity scores of 4 or 5 were taken as positive for enzyme activity, 0 or 1 were negative and 2 or 3 were considered inconclusive. All physiological tests were performed in triplicate.

The physiological characteristics of strain WCC $-2265^{\mathrm{T}}$ are consistent with those of members of the genus Actinomadura. The temperature range for growth on ISP 3 was $30-55{ }^{\circ} \mathrm{C}$, with optimal growth at $45{ }^{\circ} \mathrm{C}$. The strain grew at all tested $\mathrm{pH}$ values, but optimal growth was displayed at $\mathrm{pH}$ 6.0-9.0. The strain could tolerate up to $7 \% \mathrm{NaCl}$ in the medium and utilized D-fructose, Dglucose, myo-inositol, rhamnose, sucrose, D-xylose and, to a lesser extent, arabinose as sole carbon sources. It could not use mannitol or raffinose. Strain WCC- $2265^{\mathrm{T}}$ could be differentiated from many close phylogenetic neighbours by spore shape, ornamentation and arrangement. It could be differentiated from A. rubrobrunea DSM $43750^{\mathrm{T}}$ and A. viridilutea DSM $44433^{\mathrm{T}}$ by its production of soluble pigment, lack of aerial hyphae on ISP 3 , tolerance for $\mathrm{NaCl}$, lower growth temperature and inability to use mannitol (Table 1).

Strain WCC- $2265^{\mathrm{T}}$, A. rubrobrunea DSM $43750^{\mathrm{T}}$ and $A$. viridilutea DSM $44433^{\mathrm{T}}$ could not be differentiated based on the results of the API ZYM test kit. All strains were: positive for acid phosphatase, alkaline phosphatase, cystine arylamidase, esterase (C4), esterase lipase (C8), $\alpha$-glucosidase, leucine arylamidase, trypsin and valine arylamidase; negative for $\alpha$-fucosidase, $\alpha$-galactosidase, $\beta$-galactosidase, $\beta$-glucuronidase and $\alpha$-mannosidase; and inconclusive for
$N$-acetyl- $\beta$-glucosaminidase, $\alpha$-chymotrypsin, $\beta$-glucosidase, lipase (C14) and naphthol-AS-BI-phosphohydrolase.

Genomic DNA was extracted and purified from cell cultures using the Qiagen DNeasy blood and tissue kit as described in the supplied protocol for DNA extraction from Gram-positive bacteria (Qiagen). The 16S rRNA gene was amplified with HotStar Taq (Qiagen) using the eubacterial primers UNI27F and UNI1492R (Lane, 1991). The almost complete 16S rRNA gene sequence data were obtained by direct sequencing with an ABI 3130 Automated Genetic Analyzer (Applied Biosystems) and the primers UNI27F, UNI338F, UNI1100R and UNI1492R (Lane, 1991). BLAST analysis (Altschul et al., 1990) was used to compare the 16S rRNA gene sequence of strain WCC$2265^{\mathrm{T}}$ with sequences from the NCBI nucleotide database. Sequence alignments were generated using CLUSTAL W 1.82 (Chenna et al., 2003) and optimized visually using GENEDOC (Nicholas et al., 1997). Phylogenetic trees were constructed using the neighbour-joining method. The reliability of the phylogenetic estimates was evaluated with the SEQBOOT, DNADIST, NEIGHBOR and CONSENSE programs in the PHYLIP package (Felsenstein, 2005) and based on 1000 replications. TREEVIEW (Page, 2001) was used to generate rooted phylogenetic trees. DNA $\mathrm{G}+\mathrm{C}$ content determination and DNA-DNA hybridization were performed at the Deutsche Sammlung von Mikroorganismen und Zellkulturen (DSMZ, Braunschweig, Germany). DNA for $\mathrm{G}+\mathrm{C}$ content determination and hybridization studies was purified on hydroxyapatite as described by Cashion et al. (1977). DNA G + C content was determined by HPLC as described by Mesbah et al. (1989). DNA-DNA hybridization was performed as described by De Ley et al. (1970) with the modifications described by Huß et al. (1983) using a model Cary 100 Bio UV/VIS-spectrophotometer equipped with a Peltier-thermostatted $6 \times 6$ multicell changer and a temperature controller with in situ temperature probe (Varian).

A 1488 bp 16S rRNA gene sequence was obtained for strain WCC- $2265^{\mathrm{T}}$. BLAST analysis indicated that strain WCC$2265^{\mathrm{T}}$ was phylogenetically most closely related to members of the genus Actinomadura. The neighbourjoining dendrogram confirmed that strain WCC- $2265^{\mathrm{T}}$ was a member of the genus Actinomadura, phylogenetically most closely related to A. rubrobrunea DSM $43750^{\mathrm{T}}$ and $A$. viridilutea DSM $44433^{\mathrm{T}}$, but it formed a clade $(100 \%$ bootstrap support) that was distinct from these two species (Fig. 2). A comparison of strain WCC- $2265^{\mathrm{T}}$ with the type strains of other Actinomadura species revealed a sequence similarity of $97 \%$ with A. rubrobrunea and A. viridilutea and sequence similarities of $92-96 \%$ with all other species. The sequence dissimilarity was thus equal to or greater than the $3 \%$ divergence typically used to define different species based on 16S rRNA gene sequences (Stackebrandt $\&$ Ludwig, 1988). To assess the validity of the novel species status of strain WCC-2265 ${ }^{\mathrm{T}}$, DNA-DNA hybridization was carried out. Results indicated that strain WCC $-2265^{\mathrm{T}}$ was genetically distinct from its closest phylogenetic neigh- 
Table 1. Morphological and physiological characteristics that differentiate strain WCC $-2265^{\top}$ from the type strains of closely related species of the genus Actinomadura

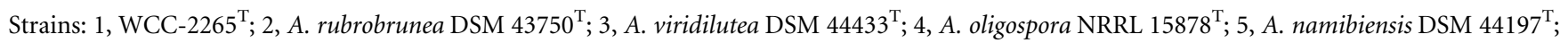
6, A. hibisca ATCC $53557^{\mathrm{T}}$; 7, A. kijaniata ATCC $31588^{\mathrm{T}} ; 8$, A. atramentaria JCM $6250^{\mathrm{T}}$. Data from: this study; Agre \& Guzeva (1975); Horan \& Brodsky (1982); Mertz \& Yao (1986); Greiner-Mai et al. (1987); Miyadoh et al. (1987); Tomita et al. (1990); Wink et al. (2003). cv, Curved; fl, flexuous; hk, hooked; sp, spiralled; st, straight; tw, twisted; gl, globose; obl, oblong; ac, aculeate; sm, smooth; bl, blue; br, brown; cl, colourless; gr, green; gy, grey; or, orange; pi, pink; wh, white; ye, yellow. +, Positive or present; -, negative or absent; +/-, inconclusive; ND, no data; TR, trace.

\begin{tabular}{|c|c|c|c|c|c|c|c|c|}
\hline Characteristic & 1 & 2 & 3 & 4 & 5 & 6 & 7 & 8 \\
\hline \multicolumn{9}{|l|}{ Conidia } \\
\hline Chain arrangement & $\mathrm{fl}-\mathrm{st}$ & $\mathrm{cV}$ & $\mathrm{cv}-\mathrm{tw}$ & $\mathrm{fl}-\mathrm{hk}$ & $\mathrm{sp}$ & st & $\mathrm{fl}-\mathrm{sp}$ & st \\
\hline Shape/ornamentation & $\mathrm{gl} / \mathrm{ac}$ & $\mathrm{gl} / \mathrm{ac}$ & $\mathrm{gl} / \mathrm{ac}$ & $\mathrm{obl} / \mathrm{sm}$ & $\mathrm{obl} / \mathrm{sm}$ & $\mathrm{obl} / \mathrm{sm}$ & $\mathrm{obl} / \mathrm{sm}$ & $\mathrm{obl} / \mathrm{sm}$ \\
\hline \multicolumn{9}{|l|}{ Colour of colony on: } \\
\hline ISP 2 & ye-or & ye-or & ye-or & br & pi & red & $\mathrm{gr} / \mathrm{br}$ & br \\
\hline ISP 4 & gy-wh & gy-wh & gy-wh & ye-gy & pi & ND & $\mathrm{gr} / \mathrm{br}$ & $\mathrm{cl}$ \\
\hline \multicolumn{9}{|l|}{ Aerial hyphae: } \\
\hline ISP 2 & $\mathrm{TR}$ & - & - & - & - & wh & wh & wh \\
\hline ISP 3 & - & wh/bl-gr & wh/bl-gr & TR & - & ND & wh & wh \\
\hline ISP 4 & - & TR & - & TR & wh & wh & - & wh \\
\hline Autolysis & - & + & + & $\mathrm{ND}$ & $\mathrm{ND}$ & ND & $\mathrm{ND}$ & ND \\
\hline \multicolumn{9}{|l|}{ Growth at/in: } \\
\hline $30{ }^{\circ} \mathrm{C}$ & + & - & - & + & + & + & + & + \\
\hline $60{ }^{\circ} \mathrm{C}$ & - & + & + & - & $\mathrm{ND}$ & - & - & - \\
\hline$>6 \% \mathrm{NaCl}$ & + & - & - & - & $\mathrm{ND}$ & - & $\mathrm{ND}$ & - \\
\hline \multicolumn{9}{|l|}{ Utilization of: } \\
\hline Arabinose & $+1-$ & - & $+1-$ & - & + & + & + & - \\
\hline D-Fructose & + & $+1-$ & + & $+1-$ & - & + & + & - \\
\hline D-Glucose & + & + & + & + & + & + & + & + \\
\hline myo-Inositol & + & $+1-$ & + & - & $+1-$ & + & + & - \\
\hline Mannitol & - & + & + & - & $+1-$ & + & - & - \\
\hline Raffinose & - & $+1-$ & - & - & - & + & - & - \\
\hline
\end{tabular}

bours. The mean DNA-DNA relatedness values (duplicate measurements) of strain WCC- $2265^{\mathrm{T}}$ with A. rubrobrunea DSM $43750^{\mathrm{T}}$ and $A$. viridilutea DSM $44433^{\mathrm{T}}$ were $43.1 \pm 1.2 \%$ and $38.3 \pm 3.1 \%$, respectively, clearly indicating that strain WCC- $2265^{\mathrm{T}}$ represents a novel species according to the $70 \%$ DNA-DNA relatedness threshold recommended by Wayne et al. (1987) for the recognition of genomic species. The DNA G $+\mathrm{C}$ content of strain WCC $-2265^{\mathrm{T}}$ was $73.7 \mathrm{~mol} \%$.

Biomass for quantitative fatty acid analysis was collected by centrifugation from cultures grown in GPYB broth (Greiner-Mai et al., 1987) for $48 \mathrm{~h}$ at $45^{\circ} \mathrm{C}$. The cellular fatty acid profiles were determined by GLC (MIDI) using the standard protocol (Sasser, 1990). Consistent with the observations of Kroppenstedt et al. (1990), A. rubrobrunea and A. viridilutea contained high amounts of iso-branched fatty acids and a low proportion of 10-methyl-branched fatty acids relative to other species of the genus Actinomadura. Strain WCC- $2265^{\mathrm{T}}$ also produced a relatively large proportion of iso-branched fatty acids, predominantly 14-methylpentadecanoic acid (iso- $\mathrm{C}_{16: 0}$ ) and 15-methylhexadecanoic acid (iso- $\mathrm{C}_{17: 0}$ ). Strain WCC- $2265^{\mathrm{T}}$ could be differentiated from Actinomadura species, including A. rubrobrunea and A. viridilutea, by the presence of a large proportion of 10-methyl heptadecanoic acid (10-methyl $\left.\mathrm{C}_{17: 0}\right)$. The complete cellular fatty acid profiles of strain WCC- $2265^{\mathrm{T}}$, A. rubrobrunea DSM $43750^{\mathrm{T}}$ and A. viridilutea DSM $44433^{\mathrm{T}}$ determined in this study can be found in Supplementary Table S1 (available in IJSEM Online).

Menaquinone analyses were carried out by the DSMZ Identification Service and B. J. Tindall (DSMZ). Quinones were extracted from $100 \mathrm{mg}$ freeze-dried cell material using 


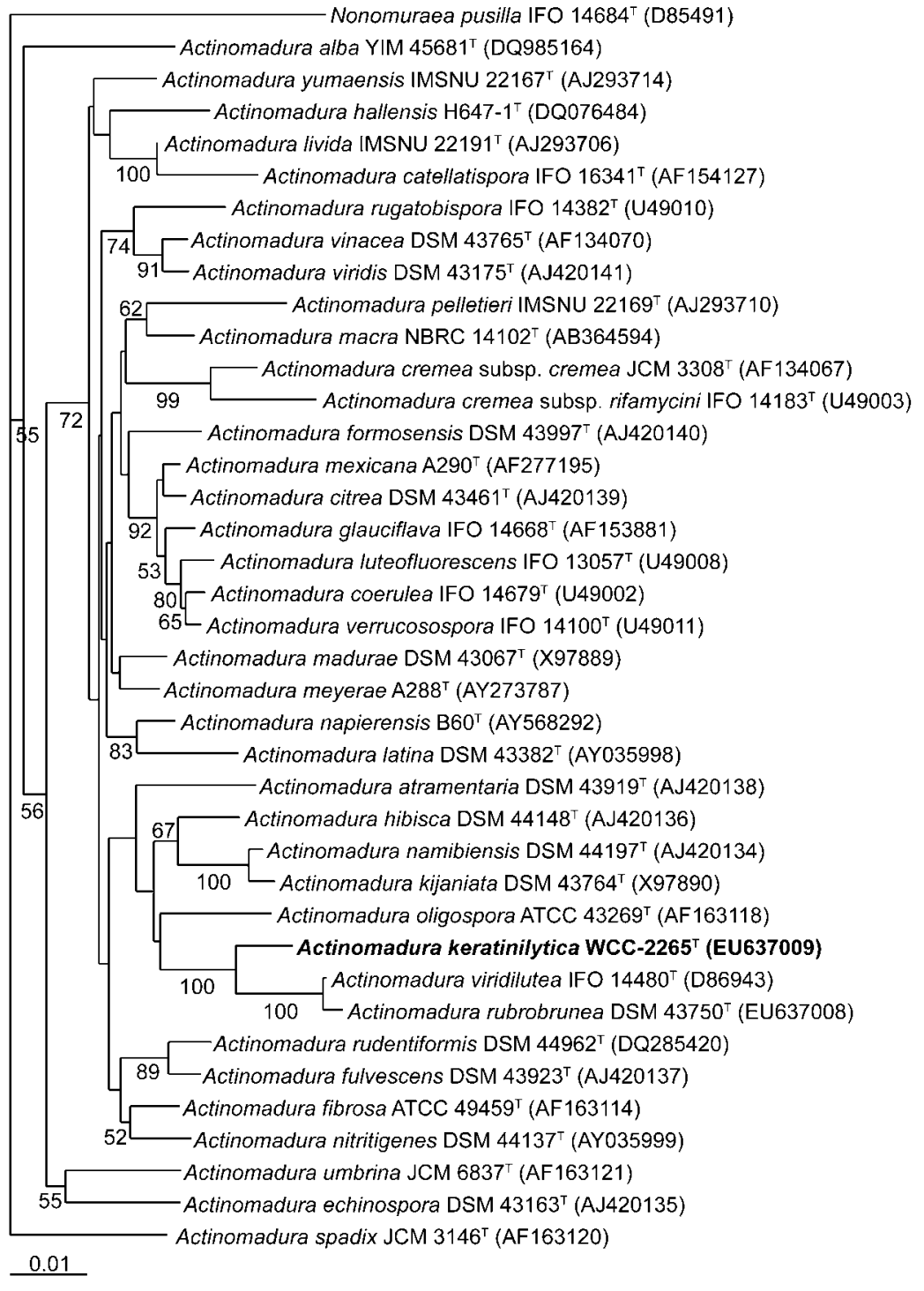

Fig. 2. Phylogenetic tree based on $16 \mathrm{~S}$ rRNA gene sequences showing the position of strain WCC- $2265^{\top}$ within the radiation of the genus Actinomadura. The sequence of Nonomuraea pusilla IFO $14684^{\top}$ was used as an outgroup. Bar, 0.01 nt substitutions per base. Numbers at nodes $(>50 \%)$ indicate support for the internal branches within the tree obtained by bootstrap analysis (percentages of 1000 bootstraps). NCBI accession numbers are presented in parentheses. methanol/hexane based on the two-stage method described by Tindall (1990a, b). Quinones were separated by TLC on silica gel, removed from the plate and further analysed by HPLC. Cell wall analysis was also performed by the DSMZ Identification Service. Preparation of cell walls and determination of peptidoglycan structure were carried out using the methods described by Rhuland et al. (1955), Schleifer \& Kandler (1972), Schleifer (1985) and MacKenzie (1987). Cell-wall sugars were analysed by a modification of the method of Staneck \& Roberts (1974). Consistent with its classification in the genus Actinomadura (Zhang et al., 2001), the cell wall of strain WCC- $2265^{\mathrm{T}}$ contained meso-diaminopimelic acid, the cell-wall sugars were of type B (madurose, galactose, glucose and ribose were present) and the major menaquinones were MK$9\left(\mathrm{H}_{6}\right)$ (accounting for $50 \%$ of the total), MK-9 $\left(\mathrm{H}_{8}\right)$ $(15 \%)$, MK-9 $\left(\mathrm{H}_{4}\right)(10 \%)$ and MK-9 $\left(\mathrm{H}_{2}\right)(3 \%)$.

Morphological, physiological and chemotaxonomic analyses indicated that strain WCC- $2265^{\mathrm{T}}$ belongs to the genus
Actinomadura; 16S rRNA gene sequence and DNA-DNA hybridization analyses indicated that it represents a novel species. Phenotypic characters and fatty acid analysis are also consistent with novel species status for strain WCC$2265^{\mathrm{T}}$. Therefore, it is concluded that strain WCC- $2265^{\mathrm{T}}$ represents a novel species within the genus Actinomadura, for which the name Actinomadura keratinilytica sp. nov. is proposed. The epithet pertains to the recovery of the strain from composting keratin, as well as its ability to degrade and utilize keratin as its sole carbon and nitrogen source. This ability is due in part to the action of at least one highly active, keratin-degrading serine protease that has been cloned from A. keratinilytica (A. A. Puhl, L. B. Selinger, T. A. McAllister and G. D. Inglis, unpublished data).

\section{Description of Actinomadura keratinilytica sp. nov.}

Actinomadura keratinilytica [ke.rat.in.i.ly'ti.ca. N.L. n. keratinum keratin; N.L. adj. lyticus - a -um (from Gr. adj. lutikos) able to dissolve; N.L. fem. adj. keratinilytica keratin-dissolving]. 
Aerobic, Gram-positive. Cells grow well on ISP 2, ISP 3, ISP 4 and KA, forming well-developed, extensively branched substrate hyphae. A brown soluble pigment is produced on ISP 2. White aerial hyphae are formed on KA, which differentiate into flexuous or straight chains of 5-15 spherical and spiny spores. Spore maturation is marked by a distinct change in the colour of the aerial hyphae to bluegreen; no autolysis of the aerial hyphae occurs. Optimal growth is at $45{ }^{\circ} \mathrm{C}$ and $\mathrm{pH}$ 6-9. D-Fructose, D-glucose, myo-inositol, rhamnose, sucrose, D-xylose and, to a lesser extent, arabinose are used as carbon sources, but not mannitol or raffinose. Tolerates up to $7 \% \mathrm{NaCl}$. Keratin can be used as the sole carbon and nitrogen source. The predominant cellular fatty acids are iso- $\mathrm{C}_{16: 0}, \mathrm{C}_{17: 0 \text {, iso- }}$ $\mathrm{C}_{17: 0}$ and 10-methyl $\mathrm{C}_{17: 0}$. The diagnostic amino acid of the cell-wall peptidoglycan is meso-diaminopimelic acid. The cell-wall sugars are madurose, galactose, glucose and ribose. The major menaquinones are MK- $9\left(\mathrm{H}_{6}\right)$, MK9( $\left.\mathrm{H}_{8}\right)$, MK-9 $\left(\mathrm{H}_{4}\right)$ and MK-9 $\left(\mathrm{H}_{2}\right)$.

The type strain, WCC $-2265^{\mathrm{T}}\left(=\mathrm{DSM} 45195^{\mathrm{T}}=\mathrm{CCUG}\right.$ $56181^{\mathrm{T}}$ ), was isolated from composting bovine manure in southern Alberta, Canada. The DNA G + C content of the type strain is $73.7 \mathrm{~mol} \%$.

\section{Acknowledgements}

The work of a number of individuals contributed to the completion of this project. We wish to thank the identification services at the DSMZ (Braunschweig, Germany) for DNA-DNA hybridization and DNA base composition analysis, analysis of the respiratory lipoquinones and cell-wall analysis. Thanks to Tara Shelton and Kathaleen House (Agriculture and Agri-Food Canada Research Centre, Lethbridge) for technical support. We are grateful to Byron Lee (AAFC, Lethbridge) for conducting the scanning electron microscopy. Determination of the cellular fatty acids and preparation of lyophilized stocks by Jay Yanke (AAFC, Lethbridge) is also gratefully acknowledged. Financial support was provided by the: (1) Alberta Prion Research Institute; (2) Canadian Centre for Security Science (Chemical, Biological, Radiological, and Nuclear Research and Technology Initiative); (3) Agriculture and Agri-Food Canada SRM targeted funding; and (4) Canada-Alberta Beef Industry Development Fund.

\section{References}

Agre, N. S. \& Guzeva, L. N. (1975). New actinomycetes genus: Excellospora gen. nov. Mikrobiologiia 44, 518-523.

Al-Musallam, A. A., Al-Zarban, S. S., Fasasi, Y. A., Kroppenstedt, R. M. \& Stackebrandt, E. (2003). Amycolatopsis keratiniphila sp. nov., a novel keratinolytic soil actinomycete from Kuwait. Int J Syst Evol Microbiol 53, 871-874.

Al-Zarban, S. S., Al-Musallam, A. A., Abbas, I., Stackebrandt, E. \& Kroppenstedt, R. M. (2002). Saccharomonospora halophila sp. nov., a novel halophilic actinomycete isolated from marsh soil in Kuwait. Int J Syst Evol Microbiol 52, 555-558.

Altschul, S. F., Gish, W., Miller, W., Myers, E. W. \& Lipman, D. J. (1990). Basic local alignment search tool. J Mol Biol 215, 403-410.

Bradbury, J. H. (1973). The structure and chemistry of keratin fibers. Adv Protein Chem 27, 111-211.
Cashion, P., Holder-Franklin, M. A., McCully, J. \& Franklin, M. (1977). A rapid method for the base ratio determination of bacterial DNA. Anal Biochem 81, 461-466.

Chenna, R., Sugawara, H., Koike, T., Lopez, R., Gibson, T. J., Higgins, D. G. \& Thompson, J. D. (2003). Multiple sequence alignment with the Clustal series of programs. Nucleic Acids Res 31, 3497-3500.

De Ley, J., Cattoir, H. \& Reynaerts, A. (1970). The quantitative measurement of DNA hybridization from renaturation rates. Eur $J$ Biochem 12, 133-142.

Felsenstein, J. (2005). PHYLIP (phylogeny inference package) version 3.6. Distributed by the author. Department of Genome Sciences, University of Washington, Seattle, USA.

Greiner-Mai, E., Kroppenstedt, R. M., Korn-Wendisch, F. \& Kutzner, H. J. (1987). Morphological and biochemical characterization and emended descriptions of thermophilic actinomycetes species. Syst Appl Microbiol 9, 97-109.

Horan, A. C. \& Brodsky, B. C. (1982). A novel antibiotic-producing Actinomadura, Actinomadura kijaniata sp. nov. Int J Syst Bacteriol 32, 195-200.

Humble, M. W., King, A. \& Phillips, I. (1977). API ZYM: a simple rapid system for the detection of bacterial enzymes. J Clin Pathol 30, 275277.

Huß, V. A. R., Festl, H. \& Schleifer, K. H. (1983). Studies on the spectrophotometric determination of DNA hybridization from renaturation rates. Syst Appl Microbiol 4, 184-192.

Kroppenstedt, R. M. \& Goodfellow, M. (1991). The family Thermomonosporaceae. In The Prokaryotes, 2nd edn, pp. 1085-1114. Edited by A. Balows, H. G. Trüper, M. Dworkin, W. Harder \& K. H. Schleifer. New York: Springer.

Kroppenstedt, R. M., Stackebrandt, E. \& Goodfellow, M. (1990). Taxonomic revision of the actinomycete genera Actinomadura and Microtetraspora. Syst Appl Microbiol 13, 148-160.

Lane, D. J. (1991). 16S/23S rRNA sequencing. In Nucleic Acid Techniques in Bacterial Systematics, pp. 115-175. Edited by E. Stackebrandt \& M. Goodfellow. Chichester: Wiley.

MacKenzie, S. L. (1987). Gas chromatographic analysis of amino acids as the $N$-heptafluorobutyryl isobutyl esters. J Assoc Off Anal Chem 70, 151-160.

Mertz, F. P. \& Yao, R. C. (1986). Actinomadura oligospora sp. nov., the producer of a new polyether antibiotic. Int J Syst Bacteriol 36, 179182.

Mesbah, M., Premachandran, U. \& Whitman, W. B. (1989). Precise measurement of the $\mathrm{G}+\mathrm{C}$ content of deoxyribonucleic acid by highperformance liquid chromatography. Int J Syst Bacteriol 39, 159-167.

Miyadoh, S., Amano, S., Tohyama, H. \& Shomura, T. (1987). Actinomadura atramentaria, a new species of the Actinomycetales. Int J Syst Bacteriol 37, 342-346.

Montero-Barrientos, M., Rivas, R., Velázquez, E., Monte, E. \& Roig, M. G. (2005). Terrabacter terrae sp. nov., a novel actinomycete isolated from soil in Spain. Int J Syst Evol Microbiol 55, 2491-2495.

Mukhopadhyay, R. P. \& Chandra, A. L. (1990). Keratinase of a streptomycete. Indian J Exp Biol 28, 575-577.

Nicholas, K. B., Nicholas, H. B., Jr \& Deerfield, D. W., II (1997). GeneDoc: analysis and visualization of genetic variation. EMBnet News 4 (2), 1-4. http://www.embnet.org/download/embnetnews/ embnet_news_4_2.pdf

Noval, J. J. \& Nickerson, W. J. (1959). Decomposition of native keratin by Streptomyces fradiae. J Bacteriol 77, 251-263.

Page, R. D. M. (2001). TreeView. http://taxonomy.zoology.gla. ac.uk/rod/treeview.html 
Rhuland, L. E., Work, E., Denman, R. F. \& Hoare, D. S. (1955). The behavior of the isomers of $\alpha, \varepsilon$-diaminopimelic acid on paper chromatograms. J Am Chem Soc 77, 4844-4846.

Sasser, M. (1990). Identification of bacteria by gas chromatography of cellular fatty acids, MIDI Technical Note 101. Newark, DE: MIDI Inc.

Schleifer, K. H. (1985). Analysis of the chemical composition and primary structure of murein. Methods Microbiol 18, 123-156.

Schleifer, K. H. \& Kandler, O. (1972). Peptidoglycan types of bacterial cell walls and their taxonomic implications. Bacteriol Rev 36, 407-477.

Shirling, E. B. \& Gottlieb, D. (1966). Methods for characterization of Streptomyces species. Int J Syst Bacteriol 16, 313-340.

Stackebrandt, E. \& Ludwig, W. (1988). 16S ribosomal RNA cataloging. Methods Enzymol 167, 132-138.

Staneck, J. L. \& Roberts, G. D. (1974). Simplified approach to identification of aerobic actinomycetes by thin-layer chromatography. Appl Microbiol 28, 226-231.

Tindall, B. J. (1990a). A comparative study of the lipid composition of Halobacterium saccharovorum from various sources. Syst Appl Microbiol 13, 128-130.

Tindall, B. J. (1990b). Lipid composition of Halobacterium lacusprofundi. FEMS Microbiol Lett 66, 199-202.
Tomita, K., Nishio, M., Saitoh, K., Yamamoto, H., Hoshino, Y., Ohkuma, H., Konishi, M., Miyaki, T. \& Oki, T. (1990). Pradimicins A, B and C: new antifungal antibiotics. I. Taxonomy, production, isolation and physico-chemical properties. J Antibiot (Tokyo) 43, 755-762.

Wayne, L. G., Brenner, D. J., Colwell, R. R., Grimont, P. A. D., Kandler, O., Krichevsky, M. I., Moore, L. H., Moore, W. E. C., Murray, R. G. E. \& other authors (1987). International Committee on Systematic Bacteriology. Report of the ad hoc committee on reconciliation of approaches to bacterial systematics. Int J Syst Bacteriol 37, 463-464.

Wink, J., Kroppenstedt, R. M., Seibert, G. \& Stackebrandt, E. (2003). Actinomadura namibiensis sp. nov. Int J Syst Evol Microbiol 53, 721-724.

Xu, W., Reuter, T., Inglis, G. D., Larney, F. J., Alexander, T. W., Guan, J., Stanford, K., Xu, Y. \& McAllister, T. A. (2009). A biosecure composting system for disposal of cattle carcasses and manure following infectious disease outbreak. J Environ Qual 38, 437-450.

Young, R. A. \& Smith, R. E. (1975). Degradation of feather keratin by culture filtrates of Streptomyces fradiae. Can J Microbiol 21, 583-586.

Zhang, Z., Kudo, T., Nakajima, Y. \& Wang, Y. (2001). Clarification of the relationship between the members of the family Thermomonosporaceae on the basis of 16S rDNA, 16S-23S rRNA internal transcribed spacer and $23 \mathrm{~S}$ rDNA sequences and chemotaxonomic analyses. Int J Syst Evol Microbiol 51, 373-383. 